\title{
In memoriam: Horacio González
}

\section{Noé Jitrik}

Lamentable suerte para la cultura argentina y latinoamericana la muerte en junio de este desdichado año 2021 de nuestro gran amigo Horacio González. Su presencia en ambos ámbitos, y su manera de estar en ellos mediante esa rara y difícil combinación entre pensamiento y acción - que en su caso era permanente y constante-, fue siempre indispensable en el general e histórico proceso de comprensión de los avatares propios de la compleja conformación de nuestras identidades nacionales. Es probable que, en ese aspecto, pueda ser comprendido como un producto de la explosión filosófica posexistencialista que acompañó y sostuvo gran parte del pensamiento latinoamericano de medio siglo de elaboración, pero al cual supo darle una dimensión original en tanto a su competencia teórica, su fuerza discursiva y su conocimiento de las disciplinas en las que transitaba, se unía un saber literario y una sensibilidad fuera de lo común en esos arduos terrenos.

En cuanto a lo que estamos llamando "acción" puede entenderse como "intervención" y "compromiso", tal, por mencionar un aspecto fundamental, la Dirección de la Biblioteca Nacional, a la cual pudo encauzar y reanimar devolviéndole una energía que la convirtió en palanca de discusión y de apertura. Volvieron con él los espíritus soterrados de Mariano Moreno, Groussac y Borges y se conjugaran en su resplandor con la nerviosidad política de la época y el deseo de generaciones jóvenes de encontrar un destino en sus archivos, en sus acervos y en sus salas de lectura. Por añadidura, la profusión de inauguraciones y homenajes, la resurrección de obras olvidadas, la música y la modernización bibliotecológica convirtieron a la Biblioteca en un polo y, lo más excepcional todavía, promoviendo y ejecutando ese fecundo hacer, y para explicarse a sí mismo cómo ese movimiento le devolvía un sentido, escribió una historia de la Biblioteca, que no era un recinto de papeles lánguidos sino un objeto epistemológico cuya significación no debería ignorarse y él no la ignoró.

No es todo y mucho menos; un aspecto fundamental de su obra fue el de sus ensayos, en particular Restos pampeanos, un libro que integra esa cadena de tentativas que comienza en 1837, en el burbujeo de los Echeverría y Alberdi, prosigue con Sarmiento, toma otra forma con Lugones y con Borges y emerge como un volcán interpretativo en la obra de Martínez Estrada, con quien González dialoga desde un lugar que no era el de los predecesores pero con la altura del polemista ilustrado, casi dejando que entre la angustia en el pensamiento, pensamiento de un estar y de un ser que estas culturas se debaten. González es un último ejemplar de ese linaje que singulariza la 
cultura argentina, un discurso que liga varios, en principio autónomos y separados, unidos por el cemento de la literatura que dulcifica el estilo y lo hace persuasivo y seductor, tal como fue en el momento inicial de ese linaje.

Todo eso quedará en el recuerdo; también su generosidad, su amabilidad y su respeto por el otro. Se diría de él que era un intelectual en el mejor sentido que puede tener esta castigada palabra, un pensante capaz de detenerse y compadecer. Su muerte nos conmueve, su lección nos dinamiza, era un maestro, un fruto exquisito de lo que la cultura argentina pudo producir. 